\title{
Kinetic Monte-Carlo Simulation of Methane Steam Reforming over a Nickel Surface
}

\author{
Palawat Unruean ${ }^{1,2}$, Teetuch Plianwong ${ }^{1,2}$, Sirawit Pruksawan ${ }^{1}$, Boonyarach Kitiyanan ${ }^{1,2, *}$ \\ and Robert M. Ziff ${ }^{3}$ \\ 1 The Petroleum and Petrochemical College, Chulalongkorn University, Bangkok 10330, Thailand; \\ palawat_tay@hotmail.com (P.U.); ohmbaby03@gmail.com (T.P.); beam_03148@hotmail.com (S.P.) \\ 2 Center of Excellence on Petrochemical and Materials Technology, Chulalongkorn University, \\ Bangkok 10330, Thailand \\ 3 Department of Chemical Engineering, University of Michigan, Ann Arbor, MI 48109, USA; rziff@umich.edu \\ * Correspondence: boonyarach.k@chula.ac.th
}

Received: 31 August 2019; Accepted: 5 November 2019; Published: 11 November 2019

check for updates

\begin{abstract}
A kinetic Monte-Carlo model was developed in order to simulate the methane steam reforming and kinetic behavior of this reaction. There were 34 elementary step reactions that were used, based on the Langmuir-Hinshelwood mechanism, over a nickel catalyst. The simulation was investigated at a mole fraction of methane between 0.1 and 0.9 , temperature of 600 to $1123 \mathrm{~K}$, and total pressure of up to 40 bar. The simulated results were collected at a steady state and were compared with the previously reported experiments. The fractional coverages of the adsorbed species and the production rates of $\mathrm{H}_{2}, \mathrm{CO}$, and $\mathrm{CO}_{2}$ were evaluated, and the effects of the reaction temperature, feed concentration, and total pressure of reactants were also investigated. The simulation results showed a similar trend with previous experimental results, and suggested the appropriate conditions for this reaction, which were a total pressure of 10 bar, with the mole fraction of methane in a range of $0.4-0.5$.
\end{abstract}

Keywords: methane steam reforming; kinetic Monte-Carlo simulation; kinetic behavior; nickel catalyst

\section{Introduction}

Reforming is one of the most important processes to produce hydrogen $\left(\mathrm{H}_{2}\right)$ and/or syngas $\left(\mathrm{H}_{2}\right.$ and (C), which can be further used in downstream processes [1-3]. Three main reactions widely studied in $\mathrm{H}_{2}$ or syngas production from methane $\left(\mathrm{CH}_{4}\right)$ are partial oxidation, dry reforming, and steam reforming [4,5]. These three reactions provide the $\mathrm{H}_{2}$ to $\mathrm{CO}$ ratio differently. Typically, partial oxidation produces syngas with $\mathrm{H}_{2}$ : $\mathrm{CO}$ ratio of 2:1. Dry reforming provides a CO-rich syngas with an $\mathrm{H}_{2}$ :CO ratio of 1:1, while steam reforming produces an $\mathrm{H}_{2}$-rich syngas with an $\mathrm{H}_{2}$ :CO ratio of 3:1 [4,5].

Methane steam reforming is generally used to produce an $\mathrm{H}_{2}$-rich syngas from methane [6,7]. The process uses steam $\left(\mathrm{H}_{2} \mathrm{O}\right)$ to react with $\mathrm{CH}_{4}$ in the presence of a catalyst. $\mathrm{H}_{2}$ is formed by the dissociation of $\mathrm{H}_{2} \mathrm{O}$ and $\mathrm{CH}_{4}$. After that, the remaining oxygen atom from $\mathrm{H}_{2} \mathrm{O}$ reacts with the remaining carbon atom from $\mathrm{CH}_{4}$ to form $\mathrm{CO}$ and $\mathrm{CO}_{2}$. During the steam reforming of methane, three main reversible reactions can take place involving two strongly endothermic reactions of methane steam reforming, as shown in Equations (1) and (2), and the moderately exothermic water-gas shift reaction, as shown in Equation (3) [7-9].

$$
\begin{array}{cr}
\mathrm{CH}_{4}(\mathrm{~g})+\mathrm{H}_{2} \mathrm{O}(\mathrm{g}) \leftrightarrow \mathrm{CO}(\mathrm{g})+3 \mathrm{H}_{2}(\mathrm{~g}) & \Delta \mathrm{H}^{\circ}{ }_{298}=+206 \mathrm{~kJ} / \mathrm{mol} \\
\mathrm{CH}_{4}(\mathrm{~g})+2 \mathrm{H}_{2} \mathrm{O}(\mathrm{g}) \leftrightarrow \mathrm{CO}_{2}(\mathrm{~g})+4 \mathrm{H}_{2}(\mathrm{~g}) & \Delta \mathrm{H}^{\circ}{ }_{298}=+165 \mathrm{~kJ} / \mathrm{mol}
\end{array}
$$




$$
\mathrm{CO}(\mathrm{g})+\mathrm{H}_{2} \mathrm{O}(\mathrm{g}) \leftrightarrow \mathrm{CO}_{2}(\mathrm{~g})+\mathrm{H}_{2}(\mathrm{~g}) \quad \Delta \mathrm{H}^{\circ}{ }_{298}=-41 \mathrm{~kJ} / \mathrm{mol}
$$

Various metals have been studied as the catalyst for this reaction, such as palladium (Pd) [10], nickel (Ni) [11], platinum (Pt) [12], ruthenium (Ru) [13], rhodium (Rh) [14], and iridium (Ir) [15]. Among these metals, nickel is typically investigated, owing to its moderate cost, good catalytic performance, and high stability at relatively high temperatures $[16,17]$. Nevertheless, the rapid deactivation on the nickel surface by carbon deposition or coking has been reported [18], as well as by the formation of an $\mathrm{NiAl}_{2} \mathrm{O}_{4}$ spinel in the $\mathrm{Ni} / \mathrm{Al}_{2} \mathrm{O}_{3}$ catalyst, leading to the reduction of the active $\mathrm{Ni}$ [19].

The kinetic behavior of methane steam reforming and water-gas shift reactions over a Ni/ $\mathrm{MgAl}_{2} \mathrm{O}_{4}$ catalyst was investigated using microkinetic modelling based on the Langmuir-Hinshelwood (LH) mechanism, with purposed elementary reaction steps. The reactions were carried out in rows of tubular reactors, with the reaction temperature between 675 and $1000 \mathrm{~K}$ and a pressure of $30 \mathrm{bar}$ [20]. The activation energy and pre-exponential factor of each elementary reaction were estimated by using the unity bond index-quadratic exponential potential (UBI-QEP) and density functional theory (DFT) calculations [21]. In addition, the kinetics of the methane steam reforming with the water-gas shift reaction were studied over a commercial $\mathrm{Ni} / \alpha-\mathrm{Al}_{2} \mathrm{O}_{3}$ catalyst, and the results indicate that hydrogen and syngas are favorably produced at a high steam-to-methane ratio with a low reaction temperature, and both $\mathrm{CO}$ and $\mathrm{CO}_{2}$ are formed as primary products [22]. Moreover, the steam reforming of methane is performed over a Ni/NiAl${ }_{2} \mathrm{O}_{4}$ catalyst, with a steam-to-carbon ratio in the range of $0.2-7.1$, at temperatures of 843,858 , and $873 \mathrm{~K}$. A Langmuir-Hinshelwood model is satisfied for these experimental data [23]. The model is then developed by considering carboxyl species ( $\mathrm{COOH})$ and active carbon as intermediates [24].

Kinetic Monte-Carlo (kMC) is one of the most effective tools for investigating the complex kinetic behavior of catalytic reactions [25]. The kMC simulations connect the gap between the microscopic scale and macroscopic scale information [26]. The kMC simulations combine the statistical and elementary reaction steps to predict the adsorption on the surface of the catalyst, surface composition, site blocking, and reaction on the surface catalyst $[27,28]$. The $\mathrm{kMC}$ of CO oxidation on the catalyst surface was modeled by Ziff, Gulari, and Barshad, and is called the ZGB model [29]. This model has been successfully applied for studying complex phenomena on the surface of a catalyst [30-34]. A two-dimensional lattice is used to represent the catalyst surface, which contains all of the catalytic sites, by evenly distributing the active sites on the lattice [25]. One of the advantages of using kMC is that some effects, such as the diffusion and lateral interactions of adsorbed species, can be included. However, the diffusion of the adsorbed species is not included in this study because, based on our previous work [34], the diffusion has only a slight effect on the production rates. Furthermore, the $\mathrm{kMC}$ simulations of the water-gas shift reaction show that the CO lateral interactions do not play an important role, because of almost no CO coverage at the final steady-state [35]. Therefore, the lateral interactions are also not included.

The purpose of this work is to develop a kMC model for methane steam reforming over a nickel catalyst, based on the LH mechanism, under an isothermal condition. The simulations were performed under various operating conditions at a steady state, and the results were compared with the experimental results reported in the literature. The effects of the lattice site, feed concentration, reaction temperature, and total pressure of reactants are revealed.

\section{Results}

In this simulation, lattice sizes of $64 \times 64,128 \times 128$, and $256 \times 256$ sites were examined under the same operating conditions, and it could be observed that the lattice size had no significant effect on the fractional coverages and rates of product formation, which is similar to the other works [34,36-38]. Therefore, the lattice size of $64 \times 64$ sites was selected in this simulation study.

To find the reaction time to reach the steady state, the fractional coverages and the production rates were simulated as a function of time. Generally, the required computational time of the kMC depends on the number of elementary step reactions and the model complexity [37]. Figures 1 and 2 
illustrate the fractional coverages and the production rates as a function of time, respectively. The steady state was reached within 0.04 milliseconds.

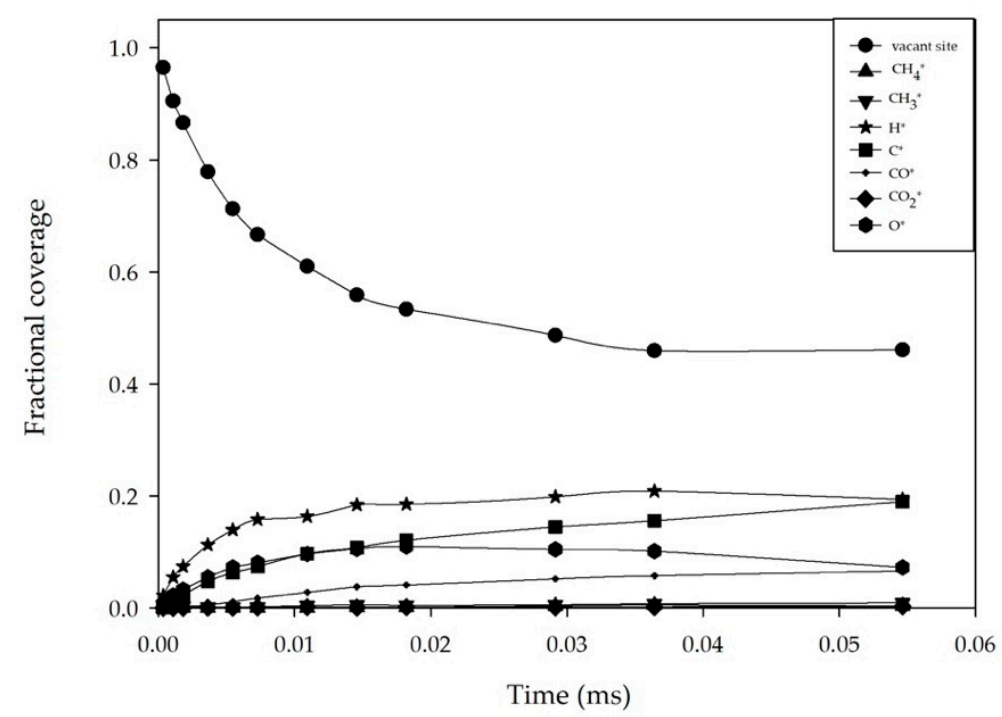

Figure 1. Fractional coverages as a function of time; time $(T)=850 \mathrm{~K}$, pressure $(P)=1$ bar, and $y_{C H_{4}}=0.5$.

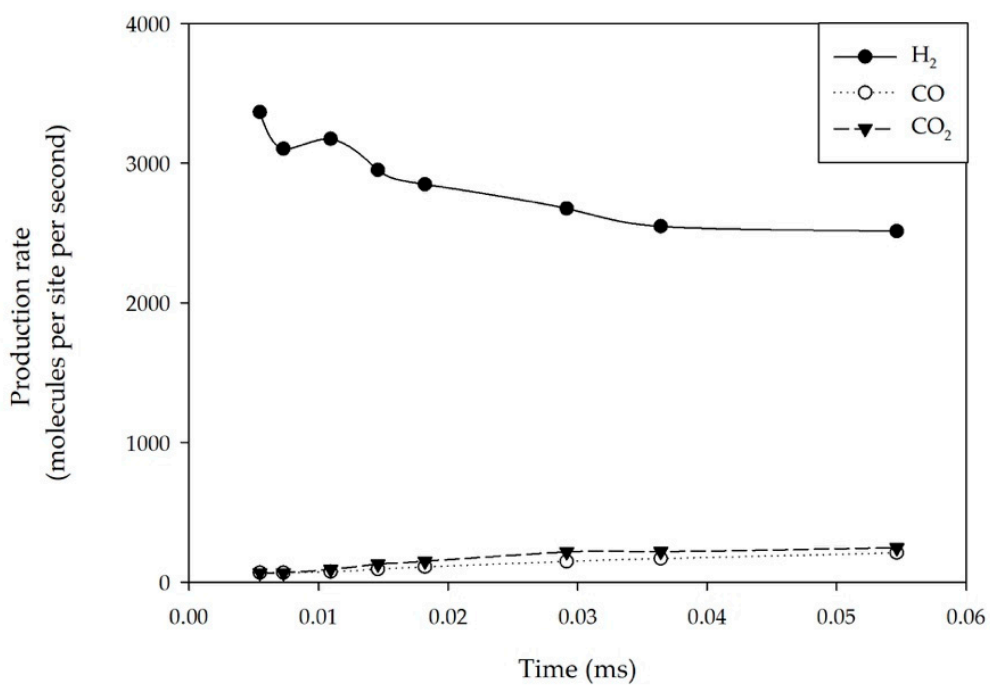

Figure 2. Production rates as a function of time; $T=850 \mathrm{~K}, P=1 \mathrm{bar}$, and $y_{\mathrm{CH}_{4}}=0.5$.

The results from this simulation were compared to those of previous experiments. At a temperature of $850 \mathrm{~K}$ and total pressure of 1 bar, the $\mathrm{H}_{2}$ : $\mathrm{CO}$ product ratio from this work was 10:1, while the $\mathrm{H}_{2}: \mathrm{CO}$ product ratio from the experiment reported by Delgado et al. [24] was approximately 6:1. In addition, both the simulated and experimental results show that the productions of $\mathrm{CO}$ and $\mathrm{CO}_{2}$ were nearly similar at these conditions.

Moreover, the relationship between $\mathrm{CO}_{2}$ selectivity and the steam-to-carbon inlet ratio $(\mathrm{S} / \mathrm{C})$ from this work was compared to that reported by Sprung et al. [39], at temperatures of 843,853 , and 873 $\mathrm{K}$. The results demonstrate that $\mathrm{CO}_{2}$ selectivity increases with the increasing $\mathrm{S} / \mathrm{C}$ ratio, and both the simulated and experimental results were about the same at all temperatures.

The $\mathrm{H}_{2}$ : $\mathrm{CO}$ ratio as a function of temperature predicted by this work was also compared to that reported by Maier et al. [40] at temperatures of 1023, 1123, and $1223 \mathrm{~K}$. The results show that the $\mathrm{H}_{2}$ :CO ratio decreases with the increasing temperature. The $\mathrm{H}_{2}: \mathrm{CO}$ ratios obtained by this simulation exhibited values of 9.7, 7.5, and 4.5, while the $\mathrm{H}_{2}: \mathrm{CO}$ ratios obtained by the experiment were 9, 7.1, 
and 5.5, respectively. Therefore, both the simulated and experimental results show about the same behavior for all of the temperatures.

\subsection{Effect of Feed Concentration}

Figures 3 and 4 illustrate the effect of the feed $\left(\mathrm{CH}_{4}\right.$ and $\left.\mathrm{H}_{2} \mathrm{O}\right)$ concentration on the fractional coverages and production rates by varying the mole fraction of methane $\left(y_{\mathrm{CH}_{4}}\right)$ between 0.1 to 0.9 at a constant temperature and pressure. It can be noticed that the reaction takes place and all of the products are formed even at a very low methane concentration $y_{\mathrm{CH}_{4}}=0.1$ ). As shown in a snapshot of the nickel surface (Figure 5a), the surface is almost entirely covered by $\mathrm{O}^{*}$ and $\mathrm{H}^{*}$ at $y_{\mathrm{CH}_{4}}=0.2$, and also by the other active species such as the active vacant site, and $\mathrm{C}^{*}$ and $\mathrm{CH}_{\mathrm{x}}{ }^{*}$ intermediates, leading to the reaction taking place.

The high yield (high rate of production) of $\mathrm{H}_{2}$ and $\mathrm{CO}$ is around $0.4<y_{\mathrm{CH}_{4}}<0.5\left(\mathrm{H}_{2}\right.$ : 2500-2700 molecules/site/second and CO: $\approx 220$ molecules/site/second for $\mathrm{CO}$ ). However, $\mathrm{CO}_{2}$ reaches the maximum yield at $y_{\mathrm{CH}_{4}}$ of 0.4 (382 molecules/site/second). The snapshot in Figure $5 \mathrm{~b}$ is also in agreement that the surface of the nickel catalyst is mainly covered by $\mathrm{C}^{*}$ and $\mathrm{H}^{*}$, together with $\mathrm{O}^{*}$, $\mathrm{CO}^{*}$, and $\mathrm{CO}_{2}{ }^{*}$. These active species are also exhibited, along with the vacant active sites, which are necessary to carry on the reactions in order to generate $\mathrm{CO}^{*}$ (steps $23,24,26$, and 28 ).

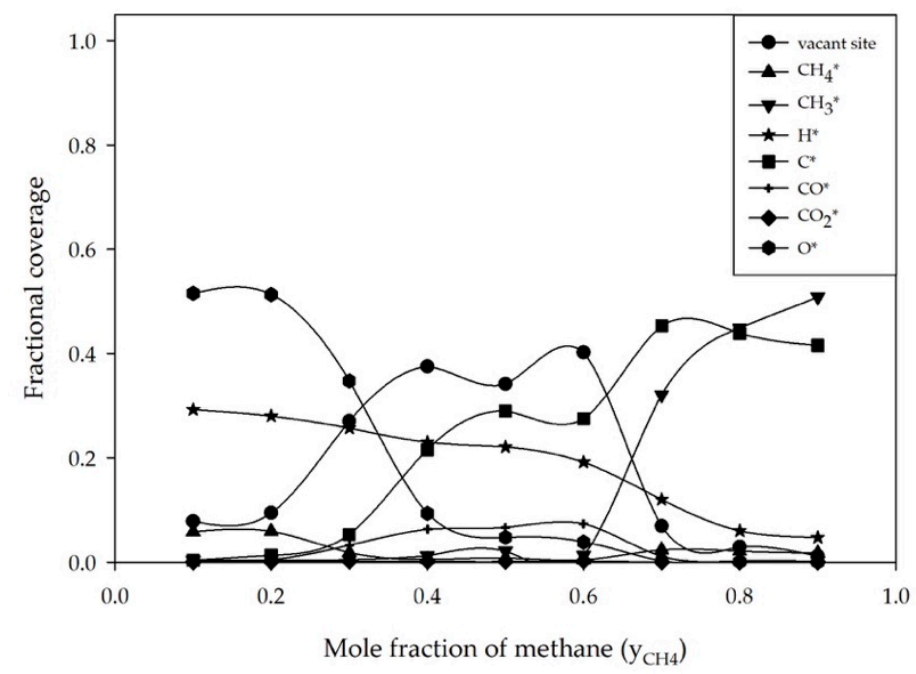

Figure 3. Fractional coverages as a function of the mole fraction of methane; $\mathrm{T}=823 \mathrm{~K}$ and $P=1$ bar.

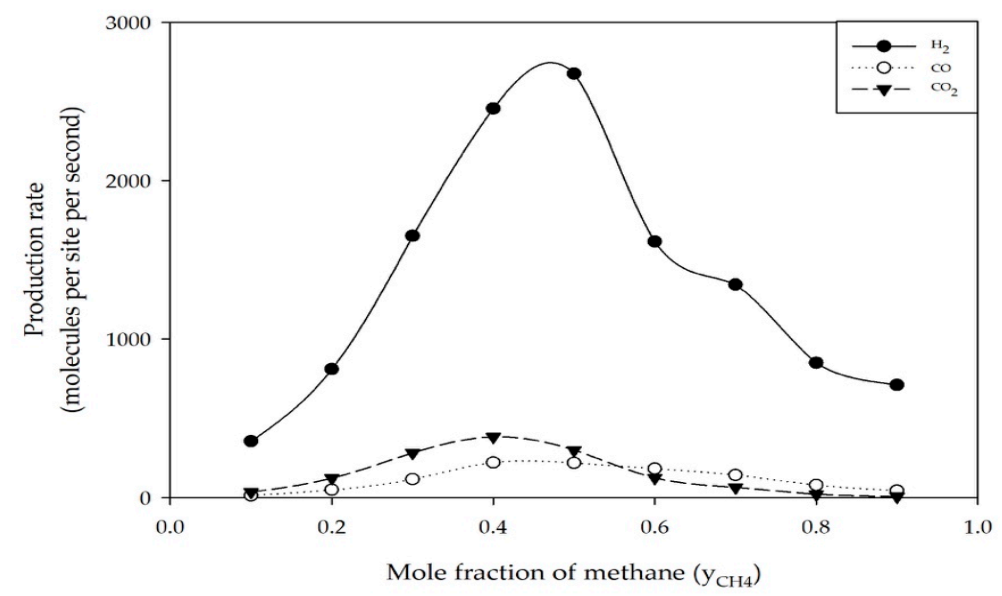

Figure 4. Production rates as a function of the mole fraction of methane; $\mathrm{T}=823 \mathrm{~K}$ and $P=1 \mathrm{bar}$. 


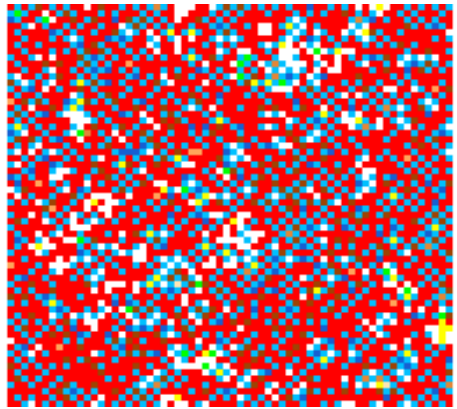

(a)

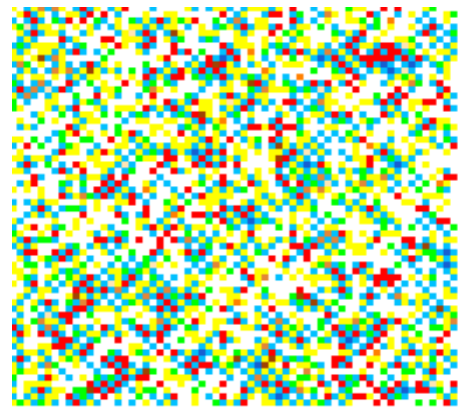

(b)

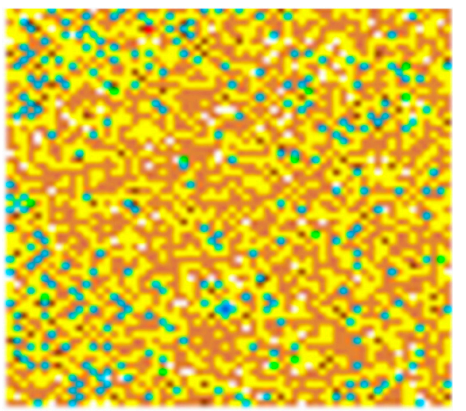

(c)

Figure 5. Snapshots of the surface of the nickel catalyst: (a) $y_{\mathrm{CH}_{4}}=0.2 ;$ (b) $y_{\mathrm{CH}_{4}}=0.5 ;$ (c) $y_{\mathrm{CH}_{4}}=0.7$; $T=823 \mathrm{~K}, P=1$ bar $\left(\square=\right.$ Empty, $\square=\mathrm{H}^{*}, \square=\mathrm{C}^{*}, \mathbf{\square}=\mathrm{O}^{*}, \mathbf{\square}=\mathrm{CH}_{4}{ }^{*}, \mathbf{m}=\mathrm{CH}_{3}{ }^{*}, \square=\mathrm{CH}_{2}{ }^{*}, \square=\mathrm{CH}^{*}$,

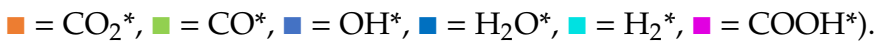

Above $y_{\mathrm{CH}_{4}}=0.5$, the production rates of $\mathrm{H}_{2}, \mathrm{CO}$, and $\mathrm{CO}_{2}$ gradually decrease and the production rates of both $\mathrm{CO}$ and $\mathrm{CO}_{2}$ products are extremely low at $y_{\mathrm{CH}_{4}}=0.9(4 \mathrm{molecules} / \mathrm{site} / \mathrm{second}$ for $\mathrm{CO}$ and 42 molecules/site/second for $\mathrm{CO}_{2}$ ). As shown in Figure $5 \mathrm{c}$, the surface of the nickel catalyst is mainly covered by $\mathrm{C}^{*}$ and $\mathrm{CH}_{3}{ }^{*}$ at $y_{\mathrm{CH}_{4}}=0.7$. Moreover, at $y_{\mathrm{CH}_{4}}=0.9, \mathrm{no}_{2}{ }^{*}$ and $\mathrm{O}^{*}$ active species are observed on the snapshot. According to these results, it is interesting to note that the optimum production rates of $\mathrm{H}_{2}$ and $\mathrm{CO}$ are obtained when $\mathrm{CH}_{4}$ and $\mathrm{H}_{2} \mathrm{O}$ are fed equally $y_{\mathrm{CH}_{4}}=0.5$ ). The vacant active sites are also important for allowing new adsorbed species as well as new elementary reactions.

\subsection{Effect of Reaction Temperature}

To observe the effect of the reaction temperature, the fractional coverages and production rates are investigated by varying the reaction temperature from 600 to $1123 \mathrm{~K}$. The results are plotted as shown in Figure 6. When $\mathrm{CH}_{4}$ adsorbs as $\mathrm{CH}_{4}{ }^{*}$ on the nickel surface, it dissociates to $\mathrm{CH}_{3}{ }^{*}$ and $\mathrm{CH}_{2}{ }^{*}$ intermediates. The $\mathrm{CH}_{4}{ }^{*}$ and $\mathrm{CH}_{3}{ }^{*}$ coverages on the surface are high at $600 \mathrm{~K}$, and as the temperature increases, both the $\mathrm{CH}_{4}{ }^{*}$ and $\mathrm{CH}_{3}{ }^{*}$ on the surface decrease. For $\mathrm{O}^{*}$, a similar trend of surface concentration is also observed. As the reaction temperature increases from 600 to $700 \mathrm{~K}$, the surface coverages of $\mathrm{C}^{*}$ and $\mathrm{H}^{*}$ increase and then decrease after $700 \mathrm{~K}$.

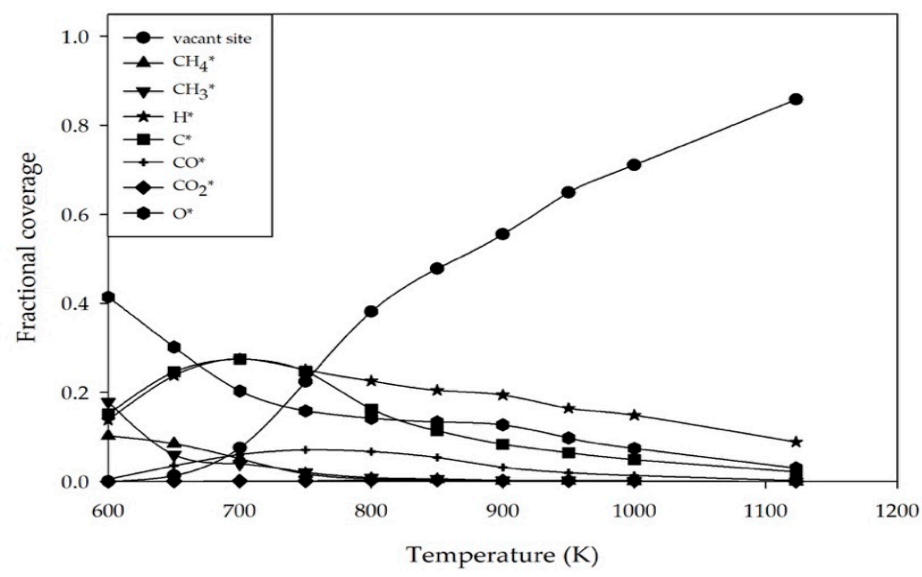

Figure 6. Fractional coverages as a function of te reaction temperature; $P=1$ bar and $y_{\mathrm{CH}_{4}}=0.4$.

Figure 7 demonstrates the production rates as a function of the reaction temperature. The results suggest that the production rates of $\mathrm{H}_{2}$ and $\mathrm{CO}_{2}$ are the highest at $750-800 \mathrm{~K}$, whereas the production rate of $\mathrm{CO}$ exhibits the highest values at a temperature range of 800-900 K. Therefore, at around $800 \mathrm{~K}$, the reaction should provide the highest yield of syngas ( 3439 molecules/site/second for $\mathrm{H}_{2}$ and 161 molecules/site/second for $\mathrm{CO}$ ). From the simulation, at a temperature higher than $750 \mathrm{~K}$, the 
fractional coverages of $\mathrm{C}^{*}$ and $\mathrm{H}^{*}$ decrease, as well as $\mathrm{O}^{*}$, possibly because of the increasing of the $\mathrm{H}_{2}$, $\mathrm{CO}$, and $\mathrm{CO}_{2}$ formation rates.

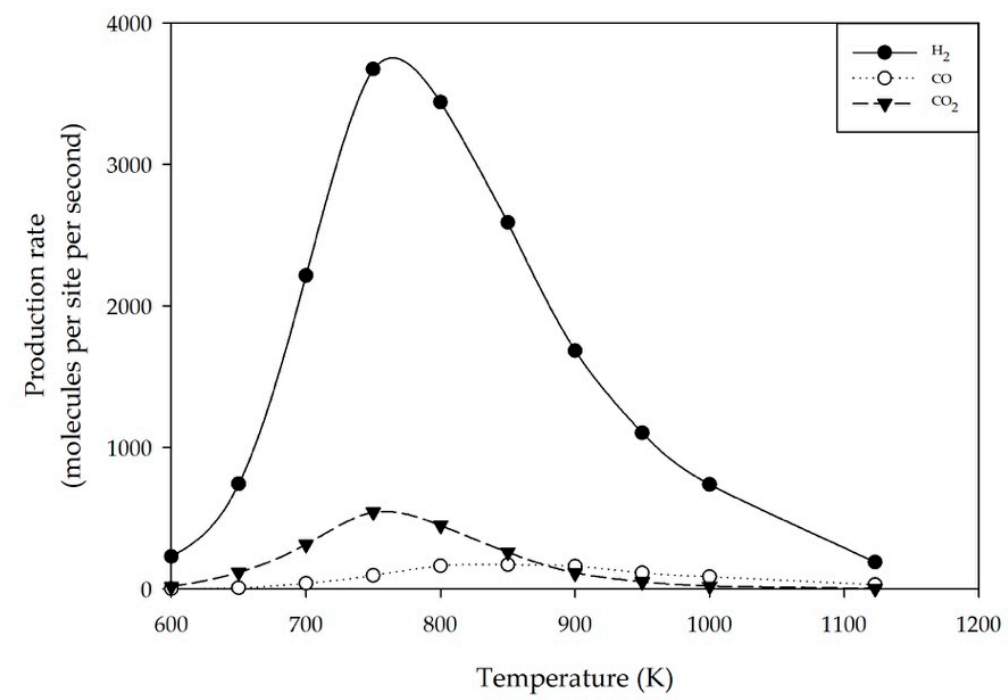

Figure 7. Production rates as a function of the reaction temperature; $P=1$ bar and $y_{\mathrm{CH}_{4}}=0.4$.

It is interesting to note that $\mathrm{CO}_{2}$ has a higher rate of production than $\mathrm{CO}$, even though $\mathrm{CO}^{*}$ can be generated by several elementary reactions (steps 23, 24, 26, and 28). However, the $\mathrm{CO}_{2}{ }^{*}$ formation (steps 25 and 30) by the adsorbed active $\mathrm{O}^{*}$ and the $\mathrm{CO}^{*}$ on the surface is easier (lower energy) than the formation of $\mathrm{CO}$ from the adsorbed $\mathrm{C}^{*}$ and $\mathrm{O}^{*}$ active species. Moreover, the $E_{a}$ of the $\mathrm{CO}_{2}$ formation (step 32) is also lower than that for the $\mathrm{CO}$ desorption (step 33). Therefore, the rate of $\mathrm{CO}_{2}$ formation is higher than the rate of $\mathrm{CO}$ formation.

Another possible reason is that the produced $\mathrm{CO}$ is strongly adsorbed on the nickel catalyst at lower temperatures [41]. From Figure 6, as the temperature increases, the $\mathrm{CO}^{*}$ on the nickel surface decreases. Furthermore, the adsorbed $\mathrm{O}^{*}$ can possibly form a non-stoichiometric nickel oxide at a temperature around 523 and $623 \mathrm{~K}$, and a nickel oxide around $723 \mathrm{~K}$ [42], leading to less $\mathrm{O}^{*}$ to oxidize $\mathrm{CO}^{*}$ to form $\mathrm{CO}_{2}$ at higher temperatures. For these reasons, the $\mathrm{CO}_{2}$ production rate is higher at lower temperatures, while $\mathrm{CO}$ production prefers a higher temperature.

\subsection{Effect of the Total Pressure of Reactants}

As expected, when the total pressure increases from 1 to 5 bar, the surface coverages of the intermediates, especially $\mathrm{CH}_{3}{ }^{*}$ and $\mathrm{C}^{*}$, increase, whereas the vacant sites significantly decrease. Above a total pressure of 5 bar, the surface coverages of all of the species are relatively constant.

As mentioned in the previous study [43], the steam reforming reaction is not favored thermodynamically at high pressures. The effect of the total pressure is studied by varying the total pressure from 1 to 40 bar at $y_{\mathrm{CH}_{4}}=0.5$. As shown in Figure 8, the production rates are remarkably increased with increasing the total pressure up to 10 bar. However, when the total pressure is higher than 10 bar, the production rates are notably decreased. 


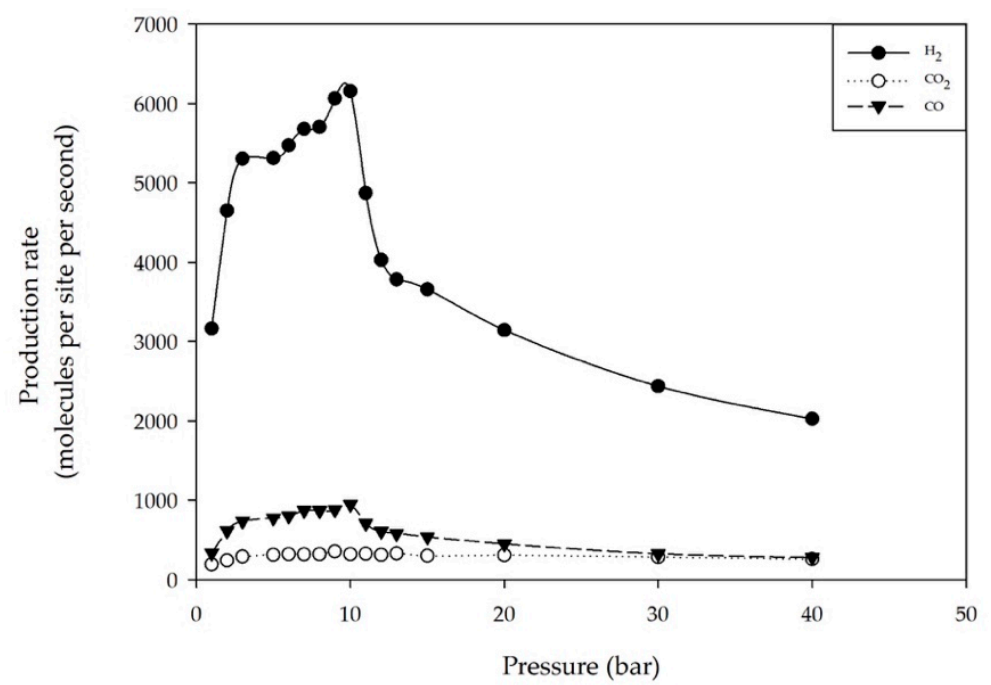

Figure 8. Production rates as a function of the total pressure; $T=823 \mathrm{~K}$ and $y_{\mathrm{CH}_{4}}=0.5$.

\section{Model and Simulation Procedure}

\subsection{Model}

The kinetics of the nickel-catalyzed methane steam reforming were first studied, based on the LH mechanism, by $\mathrm{Xu}$ and Froment [20]. The elementary reactions can be described by the following three main steps: adsorption, reaction, and desorption. After that, the microkinetic mechanism was applied to study the steam reforming of methane over the $\mathrm{Ni} / \mathrm{NiAl}_{2} \mathrm{O}_{4}$ catalyst, and 24 elementary reactions with 12 reversible reactions were proposed [39]. $\mathrm{CH}_{4}$ was adsorbed on the surface of the catalyst by dissociating into $\mathrm{C}^{*}$ and $\mathrm{H}^{*}$, while $\mathrm{H}_{2} \mathrm{O}$ was dissociated into $\mathrm{O}^{*}$ and $\mathrm{H}^{*}$. Moreover, a kinetic model on the nickel catalyst, including methane reforming and oxidation processes described by 54 elementary-step reactions, was studied by Delgado et al. [24]. Among these elementary steps, 34 steps were described as steam reforming of methane. Based on the elementary reaction steps described above, Table 1 summarizes the elementary reactions as followed by the adsorption of reactants (steps 1-2), activation of methane without oxygen (steps 3-10), activation of methane with oxygen (steps 11-18), dissociation of steam (steps 19-22), reaction (steps 23-31), and desorption of products (steps 32-34).

Our kinetic model was developed using the adsorption parameters from Sprung et al. [39], and the surface reaction and desorption parameters from Delgado et al. [24], as shown in Table 1. Steps 3, 4, $5,6,7,8,9,11,12,14,17,20,22,24,25,26,28,30,31$, and 34 are assumed to be instantaneous (possibility of an event $=1$ ), as a result of their very fast reaction (the kinetic rate is higher than $2.02 \times 10^{9} \mathrm{~s}^{-1}$ at $858 \mathrm{~K})$.

According to these data, the adsorption parameters of $\mathrm{CH}_{4}$ and $\mathrm{H}_{2} \mathrm{O}$ are 2870 and $2700 \mathrm{~Pa}^{-1} \mathrm{sec}^{-1}$, respectively, at an average temperature of $858 \mathrm{~K}$, and the adsorption rate $\left(k_{i}\right)$ in steps $1-2$ can be calculated using Equation (4), where $k_{i}^{0}$ is the adsorption coefficient, $y_{i}$ is the mole fraction of $\mathrm{CH}_{4}$ or $\mathrm{H}_{2} \mathrm{O}$ in the gas phase, and $P$ is the total pressure.

$$
k_{i}=k_{i}^{0} y_{i} P
$$

The reaction rate and desorption rate $\left(k_{i}\right)$ in steps 3-34 can be calculated using the Arrhenius equation [28,44-47] (Equation (5)), where $A_{i}$ is the pre-exponential factor, $\beta$ is the temperature exponent, $E_{a_{i}}$ is the activation energy, $R$ is the gas constant, and $T$ is the reaction temperature.

$$
k_{i}=A_{i} T^{\beta} \exp \left(-E_{a_{i}} / R T\right)
$$


Table 1. Elementary reactions and corresponding kinetic parameters used in this work ${ }^{\mathrm{a}}$.

\begin{tabular}{|c|c|c|c|c|}
\hline Steps (i) & Elementary Reaction & $A_{i}$ or $k_{i}^{0}\left(\mathrm{~s}^{-1}\right.$ or $\left.\mathrm{Pa}^{-1} \mathrm{~s}^{-1}\right)$ & $\beta$ & $E_{a_{i}}(\mathrm{~kJ} / \mathrm{mol})$ \\
\hline 1 & $\mathrm{H}_{2} \mathrm{O}(\mathrm{g})+\left[{ }^{*}\right] \rightarrow\left[\mathrm{H}_{2} \mathrm{O}^{*}\right]$ & $2.70 \times 10^{3}\left(k_{i}^{0}\right)$ & 0 & 0 \\
\hline 2 & $\mathrm{CH}_{4}(\mathrm{~g})+\left[{ }^{*}\right] \rightarrow\left[\mathrm{CH}_{4}^{*}\right]$ & $2.87 \times 10^{3}\left(k_{j}^{0}\right)$ & 0 & 0 \\
\hline $3^{b}$ & {$\left[\mathrm{CH}_{4}{ }^{*}\right]+\left[^{*}\right] \rightarrow\left[\mathrm{CH}_{3}^{*}\right]+\left[\mathrm{H}^{*}\right]$} & $4.10 \times 10^{12}$ & 0.087 & 55.8 \\
\hline $4^{\mathrm{b}}$ & {$\left[\mathrm{CH}_{3}^{*}\right]+\left[\mathrm{H}^{*}\right] \rightarrow\left[\mathrm{CH}_{4}^{*}\right]+\left[{ }^{*}\right]$} & $3.83 \times 10^{13}$ & -0.087 & 63.4 \\
\hline $5^{b}$ & {$\left[\mathrm{CH}_{3}{ }^{*}\right]+\left[^{*}\right] \rightarrow\left[\mathrm{CH}_{2}{ }^{*}\right]+\left[\mathrm{H}^{*}\right]$} & $4.10 \times 10^{15}$ & 0.087 & 98.1 \\
\hline $6^{\mathrm{b}}$ & {$\left[\mathrm{CH}_{2}{ }^{*}\right]+\left[\mathrm{H}^{*}\right] \rightarrow\left[\mathrm{CH}_{3}^{*}\right]+\left[{ }^{*}\right]$} & $8.22 \times 10^{14}$ & -0.087 & 57.2 \\
\hline $7^{b}$ & {$\left[\mathrm{CH}_{2}{ }^{*}\right]+\left[{ }^{*}\right] \rightarrow\left[\mathrm{CH}^{*}\right]+\left[\mathrm{H}^{*}\right]$} & $9.84 \times 10^{15}$ & 0.087 & 95.2 \\
\hline $8^{\mathrm{b}}$ & {$\left[\mathrm{CH}^{*}\right]+\left[\mathrm{H}^{*}\right] \rightarrow\left[\mathrm{CH}_{2}^{*}\right]+\left[{ }^{*}\right]$} & $2.60 \times 10^{16}$ & -0.087 & 81.0 \\
\hline $9^{b}$ & {$\left[\mathrm{CH}^{*}\right]+\left[{ }^{*}\right] \rightarrow\left[\mathrm{C}^{*}\right]+\left[\mathrm{H}^{*}\right]$} & $2.63 \times 10^{12}$ & 0.500 & 21.9 \\
\hline 10 & {$\left[\mathrm{C}^{*}\right]+\left[\mathrm{H}^{*}\right] \rightarrow\left[\mathrm{CH}^{*}\right]+\left[{ }^{*}\right]$} & $4.52 \times 10^{15}$ & -0.500 & 157.9 \\
\hline $11^{\mathrm{b}}$ & {$\left[\mathrm{CH}_{4}^{*}\right]+\left[\mathrm{O}^{*}\right] \rightarrow\left[\mathrm{CH}_{3}^{*}\right]+\left[\mathrm{OH}^{*}\right]$} & $1.49 \times 10^{16}$ & -0.101 & 92.7 \\
\hline $12^{\mathrm{b}}$ & {$\left[\mathrm{CH}_{3}^{*}\right]+\left[\mathrm{OH}^{*}\right] \rightarrow\left[\mathrm{CH}_{4}^{*}\right]+\left[\mathrm{O}^{*}\right]$} & $7.93 \times 10^{13}$ & 0.101 & 25.8 \\
\hline 13 & {$\left[\mathrm{CH}_{3}{ }^{*}\right]+\left[\mathrm{O}^{*}\right] \rightarrow\left[\mathrm{CH}_{2}{ }^{*}\right]+\left[\mathrm{OH}^{*}\right]$} & $3.25 \times 10^{16}$ & -0.101 & 134.6 \\
\hline $14^{\mathrm{b}}$ & {$\left[\mathrm{CH}_{2}{ }^{*}\right]+\left[\mathrm{OH}^{*}\right] \rightarrow\left[\mathrm{CH}_{3}^{*}\right]+\left[\mathrm{O}^{*}\right]$} & $3.70 \times 10^{12}$ & 0.101 & 19.0 \\
\hline 15 & {$\left[\mathrm{CH}_{2}{ }^{*}\right]+\left[\mathrm{O}^{*}\right] \rightarrow\left[\mathrm{CH}^{*}\right]+\left[\mathrm{OH}^{*}\right]$} & $3.25 \times 10^{16}$ & -0.101 & 131.3 \\
\hline 16 & {$\left[\mathrm{CH}^{*}\right]+\left[\mathrm{OH}^{*}\right] \rightarrow\left[\mathrm{CH}_{2}^{*}\right]+\left[\mathrm{O}^{*}\right]$} & $1.17 \times 10^{14}$ & 0.101 & 42.4 \\
\hline $17^{\mathrm{b}}$ & {$\left[\mathrm{CH}^{*}\right]+\left[\mathrm{O}^{*}\right] \rightarrow\left[\mathrm{C}^{*}\right]+\left[\mathrm{OH}^{*}\right]$} & $6.57 \times 10^{12}$ & 0.312 & 57.7 \\
\hline 18 & {$\left[\mathrm{C}^{*}\right]+\left[\mathrm{OH}^{*}\right] \rightarrow\left[\mathrm{CH}^{*}\right]+\left[\mathrm{O}^{*}\right]$} & $6.46 \times 10^{12}$ & -0.312 & 118.9 \\
\hline 19 & {$\left[\mathrm{H}_{2} \mathrm{O}^{*}\right]+[*] \rightarrow\left[\mathrm{H}^{*}\right]+\left[\mathrm{OH}^{*}\right]$} & $9.76 \times 10^{12}$ & -0.086 & 92.9 \\
\hline $20^{b}$ & {$\left[\mathrm{H}^{*}\right]+\left[\mathrm{OH}^{*}\right] \rightarrow\left[\mathrm{H}_{2} \mathrm{O}^{*}\right]+\left[{ }^{*}\right]$} & $4.92 \times 10^{11}$ & 0.086 & 41.5 \\
\hline 21 & {$\left[\mathrm{H}^{*}\right]+\left[\mathrm{O}^{*}\right] \rightarrow\left[\mathrm{OH}^{*}\right]+\left[{ }^{*}\right]$} & $1.05 \times 10^{15}$ & -0.188 & 104.3 \\
\hline $22^{b}$ & {$\left[\mathrm{OH}^{*}\right]+\left[{ }^{*}\right] \rightarrow\left[\mathrm{H}^{*}\right]+\left[\mathrm{O}^{*}\right]$} & $5.99 \times 10^{11}$ & 0.188 & 29.6 \\
\hline 23 & {$\left[\mathrm{C}^{*}\right]+\left[\mathrm{O}^{*}\right] \rightarrow\left[\mathrm{CO}^{*}\right]+\left[{ }^{*}\right]$} & $9.04 \times 10^{14}$ & 0 & 148.1 \\
\hline $24^{\mathrm{b}}$ & {$\left[\mathrm{C}^{*}\right]+\left[\mathrm{OH}^{*}\right] \rightarrow\left[\mathrm{H}^{*}\right]+\left[\mathrm{CO}^{*}\right]$} & $1.03 \times 10^{17}$ & 0.188 & 62.5 \\
\hline $25^{b}$ & {$\left[\mathrm{CO}^{*}\right]+\left[\mathrm{O}^{*}\right] \rightarrow\left[\mathrm{CO}_{2}^{*}\right]+\left[^{*}\right]$} & $5.32 \times 10^{10}$ & 0 & 123.6 \\
\hline $26^{\mathrm{b}}$ & {$\left[\mathrm{CO}_{2}^{*}\right]+\left[{ }^{*}\right] \rightarrow\left[\mathrm{CO}^{*}\right]+\left[\mathrm{O}^{*}\right]$} & $1.23 \times 10^{15}$ & -1.000 & 89.3 \\
\hline 27 & {$\left[\mathrm{CO}^{*}\right]+\left[\mathrm{OH}^{*}\right] \rightarrow\left[\mathrm{COOH}^{*}\right]+\left[{ }^{*}\right]$} & $1.60 \times 10^{13}$ & 0.213 & 97.6 \\
\hline $28^{\mathrm{b}}$ & {$\left[\mathrm{COOH}^{*}\right]+\left[{ }^{*}\right] \rightarrow\left[\mathrm{CO}^{*}\right]+\left[\mathrm{OH}^{*}\right]$} & $3.88 \times 10^{15}$ & -0.213 & 54.3 \\
\hline 29 & {$\left[\mathrm{CO}_{2}^{*}\right]+\left[\mathrm{H}^{*}\right] \rightarrow\left[\mathrm{COOH}^{*}\right]+\left[^{*}\right]$} & $1.66 \times 10^{16}$ & -0.475 & 117.2 \\
\hline $30^{\mathrm{b}}$ & {$\left[\mathrm{COOH}^{*}\right]+\left[{ }^{*}\right] \rightarrow\left[\mathrm{CO}_{2}^{*}\right]+\left[\mathrm{H}^{*}\right]$} & $9.92 \times 10^{11}$ & 0.475 & 33.6 \\
\hline $31^{b}$ & {$\left[\mathrm{H}^{*}\right]+\left[\mathrm{H}^{*}\right] \rightarrow \mathrm{H}_{2}(\mathrm{~g})+\left[^{*}\right]+\left[^{*}\right]$} & $6.76 \times 10^{11}$ & 0 & 95.2 \\
\hline 32 & $\left.\left[\mathrm{CO}_{2}^{*}\right] \rightarrow \mathrm{CO}_{2}(\mathrm{~g})+{ }^{*}\right]$ & $1.71 \times 10^{-1}$ & 0 & 25.9 \\
\hline 33 & {$\left[\mathrm{CO}^{*}\right] \rightarrow \mathrm{CO}(\mathrm{g})+\left[{ }^{*}\right]$} & $9.47 \times 10^{2}$ & 0 & 111.2 \\
\hline $34^{\mathrm{b}}$ & {$\left[\mathrm{H}_{2} \mathrm{O}^{*}\right] \rightarrow \mathrm{H}_{2} \mathrm{O}(\mathrm{g})+\left[{ }^{*}\right]$} & $9.92 \times 10^{3}$ & 0 & 60.7 \\
\hline
\end{tabular}

Note: $\left[{ }^{*}\right]=$ active site, $\left[\mathrm{X}^{*}\right]=$ adsorbed $\mathrm{X}$ species. ${ }^{\mathrm{a}}$ Referenced from $[24,39] .{ }^{\mathrm{b}}$ Assumed instantaneous.

\subsection{Simulation Procedure}

In the simulation, the kMC model defines the surface of the catalyst as a two-dimensional square lattice of $L \times L$ sites with periodic boundary conditions [34,48]. The lattice is in contact with an infinite reservoir of methane $\left(\mathrm{CH}_{4}\right)$ and steam $\left(\mathrm{H}_{2} \mathrm{O}\right)$, with fixed feed concentrations. The kMC algorithm consists of the following steps $[33,36,45,49]$ :

(a) Set the lattice site and initial configuration for the simulation.

(b) Select one of the lattice sites randomly.

(c) Perform the instantaneous event (steps 3, 4, 5, 6, 7, 8, 9, 11, 12, 14, 17, 20, 22, 24, 25, 28, 30, 31, and $34)$. If the conditions for the selected site and its neighboring are satisfied, the surface reaction will spontaneously take place.

(d) Calculate the possibility of an event $i\left(p_{i}\right)$, as defined by Equation (6), where $k_{i}$ corresponds to the rate constant of step $i$. An event $i$ is chosen from the possible events, except for the instantaneous event (steps 1, 2, 10, 13, 15, 16, 18, 19, 21, 23, 27, 29, 32, and 33). The possibility of each event is between 0 and 1 . This procedure is known in different sources as the Bortz-Kalos-Lebowitz (BKL), the Gillespie algorithm, or the Random Selection method [50,51].

$$
p_{i}=\frac{k_{i}}{\sum k_{i}}
$$

(e) Perform the reaction event $i$ selected in step (d) according to the following processes: 
(e-1) Adsorption

- If the adsorption of $\mathrm{H}_{2} \mathrm{O}$ (step 1) selected with a random number is $0 \leq n \leq p_{1}$ and the selected site is vacant $\left({ }^{*}\right)$, the event is successful, and steam then adsorbs into the site $\left(\mathrm{H}_{2} \mathrm{O}^{*}\right)$. If the site is occupied, the attempt is terminated.

- If the adsorption of $\mathrm{CH}_{4}$ (step 2) selected with a random number is $p_{1} \leq n \leq p_{1}+p_{2}$, the procedure will be similar to that of the adsorption of $\mathrm{H}_{2} \mathrm{O}$.

(e-2) Surface reaction

- If the surface reaction (steps 10,13,15, 16, 18, 19, 21, 23, 27, and 29) is selected with a selection number is $p_{1}+p_{2} \leq n \leq p_{1}+p_{2}+p_{\text {event }}$, and the selected site in step (b) is occupied by one of the reactants, a neighboring site next to the first site is then chosen randomly. The event is successful when the latter site is occupied by the other species of the same reaction. After that, the corresponding reaction is carried out, and both sites are then replaced by the products or one other is empty. If both sites are not occupied by the appropriate reactants, the attempt is terminated

(e-3) Desorption

- If the desorption of $\mathrm{H}_{2}, \mathrm{CO}$, or $\mathrm{CO}_{2}$ (step 31,32 , or 33 , respectively) is selected with a random number is $p_{1}+p_{2}+p_{\text {reaction }} \leq n \leq p_{1}+p_{2}+p_{\text {reaction }}+\ldots+p_{\text {desorption }}$ and the selected site in step (b) is occupied by the product, the event is successful and the product then desorbs from the site. The site is empty again because of the leaving of the product. If the site is not occupied by product, the attempt is terminated.

(f) Update the time from $t$ to $t+\Delta t$ by using Equation (7), where $r$ is a uniformly distributed random number between 0 and $1, \mathrm{~L}$ is lattice length, and $\sum k_{i}$ is the summation of all of the reaction constants, excluding the instantaneous events.

$$
\Delta t=\frac{-\ln (r)}{L^{2} \sum k_{i}}
$$

(g) Repeat the algorithm from step (b) until the steady state is obtained.

The simulation was carried out over 80,000 Monte-Carlo cycles so as to avoid the non-equilibrium behavior where one Monte-Carlo cycle equals $L \times L$ times for the events of adsorption, reaction, and desorption. The production rate $\left(R_{i}\right)$, fractional coverage $\left(\theta_{i}\right)$, and selectivity $\left(S_{i}\right)$ were computed under isothermal conditions, by taking the averages over the subsequent 80,000 Monte-Carlo cycles. The production rates of produced $\mathrm{H}_{2}, \mathrm{CO}$, and $\mathrm{CO}_{2}$ were calculated by the numbers of product molecules per lattice site in a unit of time.

\section{Conclusions}

The kinetic behavior of methane steam reforming on a nickel surface was studied using kMC simulation. This technique could provide a better understanding of the reaction comprising of several elementary steps. The snapshots at each reaction condition could hint at the events taking place on the catalyst surface.

The simulation results were in good agreement with previous experimental results, and clearly demonstrated that the reaction took place at both a low mole fraction of methane $\left(y_{\mathrm{CH}_{4}}=0.1\right)$ and a high mole fraction of methane $\left(y_{\mathrm{CH}_{4}}=0.9\right)$, as a result of the high coverages of $\mathrm{H}^{*}$ and $\mathrm{O}^{*}$ at low $y_{\mathrm{CH}_{4}}$, and the high coverage of $\mathrm{C}^{*}$ and $\mathrm{CH}_{3}{ }^{*}$ at high $y_{\mathrm{CH}_{4}}$, respectively. The methane mole fraction in a range of 0.4-0.5 showed the maximum production rates of $\mathrm{H}_{2}$ and $\mathrm{CO}$. At these mole fractions, the oxidation of $\mathrm{CH}_{\mathrm{x}}{ }^{*}$ intermediates (steps 11,13 , and 15) became the crucial reactions allowing for the subsequent elementary reactions to be carried out. The reaction temperature also played an important role on both 
the production rates and surface coverages. The catalyst surface was filled with $\mathrm{CH}_{\mathrm{x}}$ intermediates and $\mathrm{O}^{*}$ at the reaction temperature of $600 \mathrm{~K}$. The catalyst surface was then almost completely covered by $\mathrm{C}^{*}$, $\mathrm{H}^{*}$, and $\mathrm{O}^{*}$ at $700 \mathrm{~K}$. Furthermore, the effect of the total pressure illustrated that the production rates of $\mathrm{H}_{2}$ and $\mathrm{CO}$ significantly increased from a total pressure of three bar, and reached a maximum at 10 bar. Above 10 bar, the production rates of both $\mathrm{H}_{2}$ and $\mathrm{CO}$ remarkably dropped. All of the results described above suggest the reaction conditions for obtaining the highest yield of hydrogen and/or syngas.

Author Contributions: Conceptualization, T.P. and B.K.; methodology, T.P.; software, T.P. and R.M.Z; validation, P.U., S.P., B.K., and R.M.Z.; formal analysis, P.U.; investigation, T.P.; resources, T.P.; data curation, T.P.; writing (original draft preparation), P.U.; writing (review and editing), P.U., S.P., B.K., and R.M.Z.; visualization, P.U.; supervision, B.K.; project administration, P.U. and B.K.; funding acquisition, B.K.

Funding: This research was partially supported by the Center of Excellence on Petrochemical and Materials Technology, Chulalongkorn University.

Acknowledgments: P.U. expresses his thanks to the Center of Excellence on Petrochemical and Materials Technology, Chulalongkorn University, for his scholarship.

Conflicts of Interest: The authors declare no conflict of interest.

\section{References}

1. Ishaq, H.; Dincer, I. Analysis and optimization for energy, cost and carbon emission for a solar driven steam-autothermal hybrid methane reforming for hydrogen, ammonia and power production. J. Clean. Prod. 2019, 234, 242-257. [CrossRef]

2. Jokar, S.M.; Parvasi, P.; Basile, A. The performance evaluation of an industrial membrane reformer with catalyst-deactivation for a domestic methanol production plant. Int. J. Hydrogen Energy 2019, 44, 25730-25739. [CrossRef]

3. Liu, C.; Li, S.; Dong, C.; Xiao, Y.; Li, T.; Wang, W. Hydrogen-rich syngas production by chemical looping steam reforming of acetic acid as bio-oil model compound over Fe-doped $\mathrm{LaNiO}_{3}$ oxygen carriers. Int. J. Hydrogen Energy 2019, 44, 17732-17741. [CrossRef]

4. Noureldin, M.M.B.; Elbashir, N.O.; El-Halwagi, M.M. Optimization and selection of reforming approaches for syngas generation from natural/shale gas. Ind. Eng. Chem. Res. 2014, 53, 1841-1855. [CrossRef]

5. Rezaei, E.; Dzuryk, S. Techno-economic comparison of reverse water gas shift reaction to steam and dry methane reforming reactions for syngas production. Chem. Eng. Res. Des. 2019, 144, 354-369. [CrossRef]

6. Iulianelli, A.; Liguori, S.; Wilcox, J.; Basile, A. Advances on methane steam reforming to produce hydrogen through membrane reactors tecgnology: A review. Catal. Rev. 2016, 58, 1-35. [CrossRef]

7. Park, H.-G.; Han, S.-Y.; Jun, K.-W.; Woo, Y.; Park, M.-J.; Kim, S.K. Bench-scale steam reforming of methane for hydrogen production. Catalysts 2019, 9, 615. [CrossRef]

8. Navarro, M.V.; Plou, J.; López, J.M.; Grasa, G.; Murillo, R. Effect of oxidation-reduction cycles on steam-methane reforming kinetics over a nickel-based catalyst. Int. J. Hydrogen Energy 2019, 44, 12617-12627. [CrossRef]

9. Bhat, S.A.; Sadhukhan, J. Process intensification aspects for steam methane reforming: An overview. AIChE J. 2009, 55, 408-422. [CrossRef]

10. Okada, S.; Manabe, R.; Inagaki, R.; Ogo, S.; Sekine, Y. Methane dissociative adsorption in catalytic steam reforming of methane over $\mathrm{Pd} / \mathrm{CeO}_{2}$ in an electric field. Catal. Today 2018, 307, 272-276. [CrossRef]

11. Pashchenko, D. Experimental investigation of reforming and flow characteristics of a steam methane reformer filled with nickel catalyst of various shapes. Energy Convers. Manag. 2019, 185, 465-472. [CrossRef]

12. De Castro, T.P.; Silveira, E.B.; Rabelo-Neto, R.C.; Borges, L.E.P.; Noronha, F.B. Study of the performance of $\mathrm{Pt} / \mathrm{Al}_{2} \mathrm{O}_{3}$ and $\mathrm{Pt} / \mathrm{CeO}_{2} / \mathrm{Al}_{2} \mathrm{O}_{3}$ catalysts for steam reforming of toluene, methane and mixtures. Catal. Today 2018, 299, 251-262. [CrossRef]

13. Jakobsen, J.G.; Jørgensen, T.L.; Chorkendorff, I.; Sehested, J. Steam and $\mathrm{CO}_{2}$ reforming of methane over a $\mathrm{Ru} / \mathrm{ZrO}_{2}$ catalyst. Appl. Catal. A Gen. 2010, 377, 158-166. [CrossRef]

14. Chakrabarti, R.; Colby, J.L.; Schmidt, L.D. Effects of biomass inorganics on rhodium catalysts: I. Steam methane reforming. Appl. Catal. B Environ. 2011, 107, 88-94. [CrossRef] 
15. Watanabe, F.; Kaburaki, I.; Shimoda, N.; Satokawa, S. Influence of nitrogen impurity for steam methane reforming over noble metal catalysts. Fuel Process. Technol. 2016, 152, 15-21. [CrossRef]

16. Nieva, M.A.; Villaverde, M.M.; Monzón, A.; Garetto, T.F.; Marchi, A.J. Steam-methane reforming at low temperature on nickel-based catalysts. Chem. Eng. J. 2014, 235, 158-166. [CrossRef]

17. Sebai, I.; Boulahaouache, A.; Trari, M.; Salhi, N. Preparation and characterization of $5 \% \mathrm{Ni} / \gamma-\mathrm{Al}_{2} \mathrm{O}_{3}$ catalysts by complexation with $\mathrm{NH}_{3}$ derivatives active in methane steam reforming. Int. J. Hydrogen Energy 2019, 44, 9949-9958. [CrossRef]

18. Liu, C.-J.; Ye, J.; Jiang, J.; Pan, Y. Progresses in the preparation of coke resistant Ni-based catalyst for steam and $\mathrm{CO}_{2}$ reforming of methane. ChemCatChem 2011, 3, 529-541. [CrossRef]

19. Zhou, L.; Li, L.; Wei, N.; Li, J.; Basset, J.-M. Effect of $\mathrm{NiAl}_{2} \mathrm{O}_{4}$ formation on $\mathrm{Ni} / \mathrm{Al}_{2} \mathrm{O}_{3}$ stability during dry reforming of methane. ChemCatChem 2015, 7, 2508-2516. [CrossRef]

20. $\mathrm{Xu}$, J.; Froment, G.F. Methane steam reforming, methanation and water-gas shift: I. Intrinsic kinetics. AIChE J. 1989, 35, 88-96. [CrossRef]

21. Chen, D.; Lødeng, R.; Svendsen, H.; Holmen, A. Hierarchical multiscale modeling of methane steam reforming reactions. Ind. Eng. Chem. Res. 2011, 50, 2600-2612. [CrossRef]

22. Hou, K.; Hughes, R. The kinetics of methane steam reforming over a $\mathrm{Ni} / \alpha-\mathrm{Al}_{2} \mathrm{O}_{3}$ catalyst. Chem. Eng. J. 2001, 82, 311-328. [CrossRef]

23. Sprung, C.; Arstad, B.; Olsbye, U. Methane steam reforming over a Ni/ $\mathrm{NiAl}_{2} \mathrm{O}_{4}$ model catalyst-Kinetics. ChemCatChem 2014, 6, 1969-1982. [CrossRef]

24. Delgado, K.H.; Maier, L.; Tischer, S.; Zellner, A.; Stotz, H.; Deutschmann, O. Surface reaction kinetics of steam- and $\mathrm{CO}_{2}$-reforming as well as oxidation of methane over nickel-based catalysts. Catalysts 2015, 5, 871-904. [CrossRef]

25. Hess, F.; Over, H. Kinetic Monte Carlo simulations of heterogeneously catalyzed oxidation reactions. Catal. Sci. Technol. 2014, 4, 583-598. [CrossRef]

26. Andersen, M.; Panosetti, C.; Reuter, K. A practical guide to surface kinetic Monte Carlo simulations. Front. Chem. 2019, 7, 202. [CrossRef]

27. Schulze, T.P. Efficient kinetic monte carlo simulation. J. Comput. Phys. 2008, 227, 2455-2462. [CrossRef]

28. Jansen, A.P.J.; Lukkien, J.J. Dynamic Monte-Carlo simulations of reactions in heterogeneous catalysis. Catal. Today 1999, 53, 259-271. [CrossRef]

29. Ziff, R.; Gulari, E.; Barshad, Y. Kinetic phase transitions in an irreversible surface-reaction model. Phys. Rev. Lett. 1986, 56, 2553-2556. [CrossRef]

30. Loscar, E.S.; Albano, E.V. Hysteretic effects in the first-order irreversible phase transition of the ZGB model. Comput. Phys. Commun. 2009, 180, 488-492. [CrossRef]

31. Sinha, I.; Mukherjee, A.K. Monte Carlo simulation of a surface oxide model of CO oxidation. Chem. Phys. Lett. 2012, 553, 30-35. [CrossRef]

32. Buendía, G.M.; Rikvold, P.A. A model for the catalytic oxidation of $\mathrm{CO}$ that includes $\mathrm{CO}$ desorption and diffusion, O repulsion, and impurities in the gas phase. Phys. A Stat. Mech. Appl. 2015, 424, 217-224. [CrossRef]

33. De Andrade, M.F.; Figueiredo, W. Dynamical critical behavior of the Ziff-Gulari-Barshad model with quenched impurities. Phys. Lett. A 2016, 380, 2628-2631. [CrossRef]

34. Pruksawan, S.; Kitiyanan, B.; Ziff, R.M. Partial oxidation of methane on a nickel catalyst: Kinetic Monte-Carlo simulation study. Chem. Eng. Sci. 2016, 147, 128-136. [CrossRef]

35. Prats, H.; Álvarez, L.; Illas, F.; Sayós, R. Kinetic Monte Carlo simulations of the water gas shift reaction on $\mathrm{Cu}(111)$ from density functional theory based calculations. J. Catal. 2016, 333, 217-226. [CrossRef]

36. Fichthorn, K.; Gulari, E.; Ziff, R. Self-sustained oscillations in a heterogeneous catalytic reaction: A Monte Carlo simulation. Chem. Eng. Sci. 1989, 44, 1403-1411. [CrossRef]

37. Hoffmann, M.J.; Matera, S.; Reuter, K. kmos: A lattice kinetic Monte Carlo framework. Comput. Phys. Commun. 2014, 185, 2138-2150. [CrossRef]

38. Leetmaa, M.; Skorodumova, N.V. KMCLib: A general framework for lattice kinetic Monte Carlo (KMC) simulations. Comput. Phys. Commun. 2014, 185, 2340-2349. [CrossRef]

39. Sprung, C.; Kechagiopoulos, P.N.; Thybaut, J.W.; Arstad, B.; Olsbye, U.; Marin, G.B. Microkinetic evaluation of normal and inverse kinetic isotope effects during methane steam reforming to synthesis gas over a $\mathrm{Ni} / \mathrm{NiAl}_{2} \mathrm{O}_{4}$ model catalyst. Appl. Catal. A Gen. 2015, 492, 231-242. [CrossRef] 
40. Maier, L.; Schädel, B.; Delgado, K.H.; Tischer, S.; Deutschmann, O. Steam reforming of methane over nickel: Development of a multi-step surface reaction mechanism. Top. Catal. 2011, 54, 845-858. [CrossRef]

41. Osman, A.I.; Meudal, J.; Laffir, F.; Thompsom, J.; Rooney, D. Enhanced catalytic activity of $\mathrm{Ni}$ on $\eta-\mathrm{Al}_{2} \mathrm{O}_{3}$ and ZSM-5 on addition of ceria zirconia for the partial oxidation of methane. Appl. Catal. B Environ. 2017, 212, 68-79. [CrossRef]

42. Wang, C.-B.; Gau, G.-Y.; Gau, S.-J.; Tang, C.-W.; Bi, J.-L. Preparation and characterization of nanosized nickel oxide. Catal. Lett. 2005, 101, 241-247. [CrossRef]

43. Hacarlioglu, P.; Gu, Y.; Oyama, S.T. Studies of the methane steam reforming reaction at high pressure in a ceramic membrane reactor. J. Nat. Gas Chem. 2006, 15, 73-81. [CrossRef]

44. Al-Sayari, S.A. Recent developments in the partial oxidation of methane to syngas. Open Catal. J. 2013, 6, 17-28. [CrossRef]

45. Fichthorn, K.A.; Weinberg, W.H. Theoretical foundations of dynamic Monte Carlo simulations. J. Chem. Phys. 1991, 95, 1090-1096. [CrossRef]

46. Gelten, R.J.; van Santen, R.A.; Jansen, A.P.J. Chapter 18 Dynamic Monte Carlo simulations of oscillatory heterogeneous catalytic reactions. Theor. Comput. Chem. 1999, 7, 737-784.

47. Raimondeau, S.; Vlachos, D.G. Recent developments on multiscale, hierarchical modeling of chemical reactors. Chem. Eng. J. 2002, 90, 3-23. [CrossRef]

48. Cortés, J.; Valencia, E.; Araya, P. Monte Carlo simulations in the preferential oxidation of carbon monoxide on a copper-ceria catalyst. Chem. Phys. Lett. 2014, 612, 97-100. [CrossRef]

49. Cortés, J.; Valencia, E.; Araya, P. Monte Carlo simulation studies of the catalytic combustion of methane. Catal. Lett. 2006, 112, 121-128. [CrossRef]

50. Bortz, A.B.; Kalos, M.H.; Lebowitz, J.L. A new algorithm for Monte Carlo simulation of Ising spin systems. J. Comput. Phys. 1975, 17, 10-18. [CrossRef]

51. Gillespie, D.T. A general method for numerically simulating the stochastic time evolution of coupled chemical reactions. J. Comput. Phys. 1976, 22, 403-434. [CrossRef]

(C) 2019 by the authors. Licensee MDPI, Basel, Switzerland. This article is an open access article distributed under the terms and conditions of the Creative Commons Attribution (CC BY) license (http://creativecommons.org/licenses/by/4.0/). 